„Bohemistyka” 2017, nr 1, ISSN 1642-9893

Adrian PILARSKI

DOI: $10.14746 /$ bo.2017.1.4

Poznań

\title{
Erbena czarodziejskie kwiecie - motyw magicznych roślin w zbiorze Kytice
}

Keywords: Czech literature, K.J. Erben, slavic mythology, slavic gods, magical plants, magical flowers

Słowa kluczowe: literatura czeska, K.J. Erben, mitologia słowiańska, słowiańscy bogowie, magiczne rośliny, magiczne kwiaty

\section{Abstract}

In this article author discloses world of magical flowers in the poetic works of Karel Jaromír Erben, particularly in the poetic volume Kytice. Erben in his ballads represents nature not only as a work domaine of gods of the Slavs, but also as a way to control mortal ones and impact on their life. Nature is therefore an emanation of divinity and the divine world is a theater in which the role of the director's play countless slavic gods.

W artykule autor opisuje świat magicznych kwiatów w dziełach poetyckich Karla Jaromíra Erbena, szczególnie w tomiku Kytice. W swoich balladach czeski poeta ukazuje przyrodę nie tylko jako zakres działania bogów słowiańskich, ale także jako sposób kontrolowania istot śmiertelnych oraz oddziaływania na ich życie. Zatem przyroda jest emanacją bóstwa, a boski świat to teatr, w którym rolę reżyserów niezliczonych zabaw pełnią słowiańscy bogowie.

O jednym z najsłynniejszych czeskich twórców Odrodzenia Narodowego, Karlu Jaromirze Erbenie, powiedziano i pisano już wiele. Znany jako romantyczny miłośnik folkloru i folkloryzmu z pasją umieszczał słowiańskie wątki w swojej poetyckiej twórczości. Przyroda stanowi tło większości ballad zawartych w tomiku Kytice, jednak $\mathrm{w}$ niektórych $\mathrm{z}$ nich, nie tylko pełni role scenerii, ale jest terenem fantastycznej działalności słowiańskich bóstw. Erben w swoich balladach przedstawia nature nie tylko jako dzieło i dziedzine bogów Słowiańszczyzny, ale także jako ich sposób na kontrolowanie śmiertelni- 
ków i oddziaływanie na ich żywot. Każdy ptak, drzewo, tajemnicze ziele, kamień mogło być świadectwem boskiej interwencji w ludzkie życie, niosącym za sobą odpowiednie symboliczne znaczenie. Erben swoją koncepcją świata fauny i flory nawiązywał także do romantycznego rozumienia natury, która nie miała już pozostawać tylko tłem dzieł literackich, ale być czymś więcej, stać się oddzielnie egzystującym bytem. Status natury w dziełach literackich zmieniał się na przestrzeni wieków, ale to dopiero sentymentalizm oraz romantyzm jawił się, jak mówi to Maria Janion, jako

[...] widoczny przełom, nowa cezura, nadanie naturze jeszcze innego sensu niż dotąd to miało miejsce. Była „natura magiczna,,, była natura ,cudu greckiego,,, była natura renesansowa i była natura mistyków i alchemików[...]. Ale teraz pojawia się jeszcze coś innego: obdarzenie natury osobliwymi atrybutami głębokiej, pełnej egzystencji oraz wprowadzenie jej w obręb niesłychanie doniosłej dla teorii i historii kultury nowożytnej antynomii, antynomii natury i kultury. Gdy przystępujemy do rozważania preromantycznego i romantycznego sposobu istnienia natury, to powiedzmy od razu, nie idzie nam tu bynajmniej o antropomorfizowanie przyrody - idzie o udzielenie jej prawa do własnego, szczególnego, odrębnego i odmiennego życia (Janion 1989, s. 89).

Słowa te nazywają wiele prawd dotyczących natury w romantyzmie, jednak zdanie o odrębnym życiu przyrody wydaje się wyjątkowo ważne w kontekście dzieła Erbena. Demony są przecież naturalnym elementem słowiańskiej fauny, jej nieodłącznym elementem, który w romantyzmie zyskuje właśnie to s zczególne, odrębne i odmienne ży c i e. Pojawianiu się w romantycznych wierszach mitycznych stworów i demonów towarzyszyło także opisywanie ich legowisk - pieczar, mistycznych jezior, gęstych borów czy tajemniczych kotlin. Słowiański bestiariusz i otaczająca go flora, zyskały więc status żywego tworu, dodatkowo podsycanego przez rodzący się romantyczny regionalizm.

Przyroda w erbenowskim ujęciu jest zarówno życiodajna, jak niebezpieczna, a jej dobra i zła strona istnieje równolegle - pole jest źródłem pożywnego ziarna, ale też po polach wędruje polująca na dzieci południca. Podobnie las, miejsce pełne grzybów i jagód, jest siedli- skiem nieprzyjaznych dla ludzi duchów i stworzeń, w tym wił czy rusałek. Paralelnie inne miejsca - rzeczne wybrzeża, jeziora, góry, doliny a nawet ludzkie osady - są nacechowane raz pozytywnie, a innym razem negatywnie. Na to nacechowanie ma duży wpływ cykl dnia i nocy oraz przeciwstawne do siebie postaci Słońca i Księżyca. W słowiańskiej mitologii, tak jak w większości wierzeń innych ludów, te dwie siły były reprezentowane przez odpowiednie bóstwa czy grupy bóstw, np. Księżyc był analogicznie do bogini Diany przypisywany leśnej pannie Dziewannie czy inaczej Dziewicy. Obie boginie były ściśle związane z lasem i leśną zwierzyną, uważano je także za wiecznie nieskalane. Jednak Dziewanna nie tyle była boginią księżyca, co jego partnerką, rolę jej partnera pełnił uosobiający Księżyc Jasień, Niebieski Dziedzic (Niedzielski 2000, s. 4). Natomiast moc słoneczną w mitologii słowiańskiej reprezentowały bóstwa ogniowe i słoneczne, takie jak Swaróg czy Dadźbóg, które - według A. Gieysztora - miały nawiązywać do wedyjskiej triady bóstw ogniowych: Surji, Indry i Agniego, władających odpowiednio ogniem ziemskim, atmosferycznym i niebiańskim, czyli Słońcem (Gieysztor 1982, s. 132). Analogicznie to, co w boskim świetle dnia wydawało się miłe i radosne, pozbawione go i oświetlone światłem księżyca mogło być przerażające i demoniczne.

Ten obraz natury w dziele Erbena nie jest oczywiście przypadkowy, a wynika z szeroko zakrojonych studiów autora nad religijnymi i ludowymi zwyczajami Słowian. Świat słowiański był przepełniony czczonymi przez ludzi istotami, które zamieszkiwały przeróżne miejsca: od stodoły czy chałupy po niezdobyte góry i chmury biegnące po niebie. Miejsca kultu były po prostu tak zróżnicowane, jak potrzeby religijne (Gieysztor 1982, s. 168). Wyjątkowo ważną rolę odgrywały kamienie, woda oraz święte gaje i drzewa - większe miejsca kultu często obejmowały wszystkie te elementy, mniejsze - choćby jedno, pojedynczy głaz czy drzewo mogły stanowić miejscową świątynię danego bóstwa. W tym przypadku trudno mówić o konkretnych przedstawieniach bogów, w przeciwieństwie do wielu innych mitologii, np. uczłowieczającej bogów mitologii greckiej czy animizującej wiary 
starożytnych Egipcjan. Oczywiście istnieją różne przykłady totemów i drewnianych figur, jednak są one o wiele rzadsze, a większość z nich została zniszczona w czasach chrystianizacji terenów słowiańskich. Dlatego też wielu obserwatorom chrześcijańskim i niektórym uczonym zamierzchłych czasów mogło się wydawać, że Słowianie czczą konkretne drzewa czy kamienie (Gieysztor 1982, s. 172), gdy tak naprawdę posyłali oni swoje modły do bogów reprezentowanych przez dany gatunek drzewa czy kształt i rodzaj kamienia.

Wydaje się, że spośród trójcy magicznych miejsc Słowianie największą cześć oddawali jednak lasom i konkretnym drzewom, nie kamieniom czy wodzie, choć połączenie ich wszystkich stanowiło rozwiązanie najlepsze, np. strumyk, który wypływał z korzeni świętych drzew, uważany był przez Słowian za źródło życia i zdrowia. Jako święte traktowano różne gatunki drzew, w tym dąb, lipę, jawor, wiąz i jesion, które otaczano odpowiednią ochroną oraz przypisywano im lecznicze działanie (Gieysztor 1982, s. 172). Do kolekcji świętych drzew należała także wierzba, szczególnie biała, w której dostrzegano zdolności lecznicze ${ }^{1}$ oraz pomocnicze w uzyskiwaniu proroctw i wieszczb (Macioti 1998, s. 48-49). Istniały także drzewa nacechowane negatywnie, o których wierzono, że są źródłem złej energii i skrywają w sobie demony i czarty. Najmroczniejszymi drzewami były czarna olcha oraz trujący cis (Macioti 1998, s. 254). Oba często spotykano razem, co tworzyło przerażajacy demoniczny duet - drzewa nieszczęść i owoców śmierci. Jak pisze włoska socjolog, Maria Macioti:

$\mathrm{Z}$ racji charakterystycznego dlań, głębokiego cienia, obok czarnej olszy stoi cis, w którego pniu może skryć się jakakolwiek istota. Wydaje owoce cmentarne, jest jawnie związany ze światem pozagrobowym, do tego stopnia, że według starożytnych przebywanie w jego cieniu groziło śmiercią (Macioti 1998, s. 49).

Drzewa przynoszące śmierć i te, które uzdrawiają, dają profetyczne wizje. Ten bogaty świat świętych drzew jest obecny także w kilku

\footnotetext{
${ }^{1}$ Notabene, naprawdę je posiada, zawiera salicynę, środek o działaniu przeciwgorączkowym.
}

balladach Erbena. Wydaje się nawet, że poeta przełamuje dość kanoniczne dla refleksji Odrodzenia Narodowego przeciwstawienie pary dąb - lipa, w których pierwsze drzewo, symbol siły, utożsamiano przede wszystkim z plemieniem Germanów, a drugie, identyfikowano z łagodnością, z plemieniem Słowian (Macura 1995, s. 92). Erben dociera tym sposobem do głębszych pokładów słowiańskości, ignorując naddaną przez budzicieli symbolikę lipy, która do dziś jest emblematem czeskości, chętnie wykorzystywanym w mediach i kampaniach wyborczych.

W świecie poetyckim ballad zamieszczonych w zbiorze Kytice nie może także zabraknąć magicznych roślin zielnych i kwiatów, którym przypisywano różnorodne działania, od leczniczych po wywołujące zauroczenie czy szał. Wiele $\mathrm{z}$ tych roślin ma rzeczywiście terapeutyczne działanie, jednak części z nich Słowianie nadawali raczej fantastyczne właściwości, oparte na krążących wokół nich mitach. Wiele z tych mitów obrosłych wokół roślin ma swoje korzenie w wierzeniach wcześniejszych niż słowiańskie, czego dowodzi ich obecność w różnych kulturach opartych na kulturze greckorzymskiej. Nie dziwi więc, że pojawiają się one w mitologii i ludowości słowiańskiej, które część z owych wierzeń w pewnym stopniu zmodyfikowały,jednak ich korzeń symboliczny najczęściej pozostał taki sam.

Sama nazwa zbioru ballad - Kytice, czyli bukiet lub wiazanka, podkreśla ważną rolę kwiatów i ziół w tomiku. Nazwa odwołuje się także do mnogości tematów, które porusza poeta, podobnie jak w bukiecie znajdziemy wiele różnych odmian kwiatów, każdy inny, o innej symbolice. W tym przypadku Erben z całą pewnością nawiązywał do modnej wówczas w Czechach, ale także w całej Europie, mowy kwiatów. Obecne rozumienie tego terminu najczęściej ogranicza się do tematów związanych z florystyka, ale w czasach Erbena mowa kwiatów, po czesku květomluva, była pewnego rodzaju formą kulturowej komunikacji. Symbolikę kwiatom zaczęto nadawać już w arabskich haremach, wykorzystując ją wówczas do tajemnej wymiany informacji. Jednak, jak zaznacza czeski badacz Vladimír Macura, symbolikę tę w czasach Odrodzenia Narodowego wzbogaciły prężnie rozwi- 
jające się kierunki literackie, takie jak sentymentalizm, romantyzm czy biedermeier (Macura 1995, s. 20-21). Szczególną rangę wśród czeskich budzicieli zyskały róża i lilia, które stały na szczycie hierarchii kwiatowej symboliki, jedna jako symbol piękna, druga jako symbol czystości i niewinności. Obok kwiatów uważanych za szlachetne i królewskie w czeskiej sztuce mowy kwiatów zaczęto zwracać uwagę też na rośliny pomniejsze, o słabiej zarysowanym ,,potencjale kulturowym” (Macura 1995, s. 20-21). Te ,proste” kwiaty były często utożsamiane z czeskością oraz z docenianiem tego, co swojskie, choć drobne i mało efektowne. $Z$ czasem zaczęto używać tej przeciwstawnej pary w tytułach, i nie tylko, dzieł literackich, tam, gdzie pojawiał się kwiat ,szlachetny", tam też oczekiwano literatury wysokiej i wzniosłej. Natomiast gdy w dziele przywoływano wiele ,prostych”, swojskich roślin, to takie dzieło utożsamiane było z czymś surowym i skromnym (Macura 1995, s. 24). Dlatego też w tytułach ,swojskich” tomików poezji powracały fiołki, konwalie czy żonkile, natomiast w dziełach mierzących wyżej - róże lub lilie. Z czasem te dwie rośliny zyskały jeszcze większe uznanie, za sprawą swoich kolorów - czerwonego, białego oraz niekiedy niebieskiego. Barwy te są uważane za narodowe u Czechów, więc kwiaty te, obok czeskiej lipy, tworzyły razem idealne patriotyczne trio (Macura 1995, s. 29).

\section{Wisielczy sznur a mityczny kwiat paproci - Dceřina kletba}

Ballada Dceřina kletba stanowi przykład dzieła pozornie nieopartego na źródłach mitologicznych, a raczej odwołującego się do ludowej moralności i jednej z odsłon literackiej reprezentacji matczynej miłości. Jednak w utworze obecny jest, dość mocno zaznaczony, motyw poszukiwania kwiatu, i to nie jakiegokolwiek, ale posiadającego magiczną moc, czyniącego cuda. Magicznym kwiatem Słowiańszczyzny jest przede wszystkim kwiat paproci, nazywany też kwiatem Peruna, jednak dużą moc w ludowej magii przypisywano także tr o j n i k o w i, który w zależności od regionu nazywał się dziurawiec, dziewanna lub krwawnica (Niedzielski 2016, s. 18). Sama nazwa paproć była na terenach Słowiańszczyzny używana do opisywania wielu różnych roślin, dlatego, choć Erben w balladzie wspomina tylko o „kwiecie", można się domyślać, że ma na myśli jedną z wyżej wspomnianych bylin:

\section{Půjdu hledat květu toho,}

matko má!

půjdu hledat květu toho,

kterýž snímá viny mnoho

a zbouřenou chladí krev.

$$
\text { (Erben 2012, s. 141) }
$$

Wydaje się to jeszcze bardziej oczywiste, jeżeli weźmiemy pod uwagę fakt, iż w słowiańskich wierzeniach zasób znaczeń mitycznych, którymi obrosły wspomniane magiczne rośliny, jest naprawdę pokaźny i nawiązuje do wielu innych mitów:

Opowiadanie o kwiecie paproci jest często traktowane jako odmiana wschodnich legend o magicznym zielu czy magicznym diamencie króla Salomona „Szamirze” (http://www.zwoje-scrolls.com/zwoje17/text18.htm, dostęp: 15.04.2016).

Poszukiwanie kwiatu paproci było przede wszystkim związane ze słowiańskim obrzędem nocy świętojańskiej, podczas której zakochani wypatrywali w lasach wspomnianej rośliny, aby przyniosła im szczęście i pomyślność w miłości. Jednak symbolika samego kwiatu paproci jest o wiele szersza, o czym można się przekonać w erbenowskim ujęciu tematu.

Trzon fabuły ballady Dceřina kletba stanowi historia kobiety, morderczyni swego dziecka, która wyznaje winę matce. Czyn wydaje się z początku niewybaczalny, jednak pozostaje jakiś cień szansy na odkupienie grzechów, uzależniony od znalezienia magicznego kwiatu. W tym przypadku symboliczny kwiat paproci oplata wisielczy sznur, na którym ma powiesić się dziewczyna, aby zmazać swoją winę:

Tam, za branou nad vršíkem,

$$
\text { matko má! }
$$

tam za branou nad vršíkem na tom sloupu se hřebíkem, 
na konopné oprátce!

$$
\text { (Erben 2012, s. 142) }
$$

Kwiat $\mathrm{w}$ tym przypadku staje się symbolem ostatecznej kary śmierci, największego poświęcenia, które jest potrzebne, aby przywrócić kosmiczną harmonię ${ }^{2}$. Nim dziewczyna odejdzie z tego świata, rzuca na matkę klątwę za to, że wychowała ją na lekkoduszną i nierozsądną:

\section{Kletbu zůstavuji tobě, matko má! \\ kletbu zůstavuji tobě}

bys nenašla místa $\mathrm{v}$ hrobě,

žes mi zvůli dávala!

(Erben 2012, s. 142)

Według badań Anny Engelking rzucenie klątwy przez dziecko na rodziciela jest w większości przypadków uważane za grzech, ludowa etyka wydaje się kategorycznie zakazywać dzieciom przeklinania rodziców, a złamanie tego zakazu prowadzi do zasłużonej kary. Jedynym wyjątkiem, który podaje badaczka, mogłaby być krzywda, jaką zadała matka swojemu dziecku. Klątwa w tym przypadku była uzasadniona, ponieważ prowadziła do wymierzenia sprawiedliwości przez boskie siły (Engelking 2010, s. 185-199). Sytuacja przedstawiona w balladzie z pewnością dotyczy „klątw z poczucia krzywdy”, prze-

${ }^{2}$ U Słowian istnieją odwieczne, kosmogoniczne, binarne przeciwieństwa dobra i zła, ognia i wody, śmierci i życia. Pomimo mieszania się obu sił, chwilowej przewagi jednej strony nad druga, w ostatecznym rozrachunku zawsze udaje się zachować boski i kosmiczny ład. Badacz mitologii słowiańskiej, Aleksander Gieysztor, mówi o wielu mitach kosmogonicznych u Słowian, ale zaznacza, że w każdym $\mathrm{z}$ nich istnieje przeciwstawna para, na której poszczególne mity są zbudowane. Badacz podkreśla, że „Przeciwstawienie binarne, rozkładające zespół możliwości na pary i należące do podstawowych, archaicznych sposobów poznania rzeczywistości, służyło nie tylko do budowania fundamentów systemu etycznego, ale i do widzenia całokształtu świata" (Gieysztor 1982, s. 162). Dualizm świata więc wymagał od Słowian dążenia do wyrównania udziału sił dobra i ciemności w swoim życiu, niekiedy nawet bez ich świadomości i wbrew ich woli. cież również matka dziewczyny symbolicznie zabiła swe dziecko, nie dając jej odpowiedniego wychowania i doprowadzając do zabójstwa wnuka.

Na początku ballady pojawia się też święte zwierzę, w tym przypadku metafora niewinności, biały gołąb, który symbolizuje nieskalane grzechem dzieciątko dziewczyny. Młoda kobieta wmawia matce, że zabiła gołębia, a nie własne dziecko. Jednak później, w trakcie rozmowy z matką, przerażająca prawda wychodzi na jaw. Erben łączy w tej balladzie dość wątłą nić ludowych wierzeń ze zwykłym ludzkim dramatem i związanymi z nim emocjami. Kwiat paproci jest tutaj symbolem wyzwolenia młodej duszy, która popełniła grzech $\mathrm{z}$ własnej głupoty i z powodu złego wychowania przez matkę. Kwiat paproci przeistacza się w wisielczą pętlę, dzięki której dusza dziewczyny oczyści się z dokonanej zbrodni.

\section{Magiczne ziele wróżek - ballada Kytice}

Do grupy ballad opowiadających o magicznych kwiatach i podaniach z nimi związanymi, należy też utwór Kytice. Jest to krótka ballada otwierająca cały tomik. Motywem głównym utworu pozostaje miłość, której niestraszne sa nawet okowy śmierci. I nie jest to miłość kochanków, jak często zdarza się w przypadku tego motywu, lecz miłość macierzyńska, która okazuje się tak wszechmocna, że na ziemi, gdzie pochowano zmarłą matkę, wyrosło całe poletko kwiatów macierzanki:

I zželelo se matce milých dítek; duše její se vrátila

a vtělila se v drobnolistý kvítek,

jímž mohylu svou pokryla

$$
\text { (Erben 2012, s. 44) }
$$

Zioło to uważane było za ochronne i potężne nie tylko w mitologii słowiańskiej, darzone bywało także czcią w starożytnej Grecji i Egipcie. Uznaje się je za ulubiony kwiat wróżek i ich wysłanniczek pszczół. Napar z tymianku, doprawiony szczyptą innego magicznego 
ziela, miał być sposobem na zobaczenie królestwa wróżek (Macioti 1998, s. 49). Kwitnący tymianek jest więc zielem, które pozwala na ujrzenie dobrych i złych duszków, któż wie, może zmarła matka przeistoczyła się w kapryśną wróżkę, by móc spotykać się ze swoimi dziećmi. Nazwa w języku czeskim jeszcze bardziej podkreśla funkcję, jaką ziele macierzanki pełni w tej balladzie: mateřidouška. W wolnym thumaczeniu oznacza ona „duszę matki”, czyli bezpośrednio nawiązuje do swej roli, jaką pełni w balladzie: roślina staje się bowiem jedyną formą kontaktu między światem rzeczywistym a światem bajkowym, między światem żywych a światem podziemnym. Dusza matki dzięki swoim pociechom będzie miała także okazję zobaczyć pozostałych członków swojej rodziny, za sprawą tytułowego bukieciku z kwiatów macierzanki:

$$
\begin{aligned}
& \text { Ve skrovnou já tě kytici zavážu, } \\
& \text { ozdobně stužkou ovinu; } \\
& \text { do širých zemí cestu ti ukážu, } \\
& \text { kde př́buznou máš rodinu } \\
& \text { (Erben 2012, s. 44) }
\end{aligned}
$$

Moc ziela tymianku działa na leśne duszki nawet po ścięciu, dlatego matka będzie mogła być ze swymi dziećmi wszędzie i przypominać im o swej matczynej miłości.

\section{Wila ukryta w drzewie - ballada Lilie}

Równie „kwiecistą” balladą jest ballada Lilie, opowiadająca historię na pozór wesołą, ale z dość gorzkim zakończeniem. Erben sięgnął tutaj po motyw kwiatu lilii, w który po swej śmierci zamienia się młoda dziewczyna:

Neminul ještě ani rok a den,

hrob její drobným vřesem povlečen;

nepřrišlo ještě ani do tř́ let,

na jejím hrobě vzácný květe květ.

Lilie bílá - kdo ji uviděl,

každého divný pojal srdce žel; lilie vonná - kdo ji pocítil,

$\mathrm{v}$ každém se touhy plamen roznítil

(Erben 2012, s. 136)

Ma się wrażenie, że postać dziewczyny, a następnie kwiat, przeradza się w duszę uwięzioną w postaci lilii-wiły. Wiły były o wiele bardziej znane na terenach południowej Słowiańszczyzny, jednak ich obecność poświadczona jest również u Słowian zachodnich i wschodnich, znano je tam pod nazwami dziwożony lub rodzianice. Ich postacie przedstawiano jako piękne, nagie kobiety, które potrafiły przemieniać się w różne zwierzęta i rośliny (por. hasło wity w: Strzelczyk 1998, s. 230-231). Były odpowiednikiem greckich nimf leśnych, tańczących do upadłego w ,wilnym kole” (Brückner 1985, s. 305). Miały jednak dość kapryśną naturę, potrafiły zarówno pomagać, jak i szkodzić. Często sprowadzały na ludzi szaleństwo, a niekiedy porywały nieświadomych zagrożenia młodzieńców do lasu i, rzucając na nich urok, kazały im zatańczyć się na śmierć (Brückner 1985, s. 6). Motyw demonicznych kobiet nie jest oczywiście znany tylko w mitologii słowiańskiej, istnieje w każdej kulturze od czasów starożytności, wystarczy na przykład przypomnieć żonę Lucyfera Lilith czy mamiące mężczyzn średniowieczne Sukuby.

W balladzie Lilie młodzieniec przywołuje wiłę poprzez dbanie o lilię, w której zamknięta została dusza zmarłej ukochanej. Demonica powoli przekonuje do siebie młodzieńca, każe mu opiekować się lilią, by w końcu zamieszkać z nim i urodzić mu dziecko. Trudno stwierdzić, ile podstępu jest $\mathrm{w}$ zachowaniu dziwożony, ponieważ przemawia przez nią miłość zmarłej ukochanej. Wiarygodności wile dodaje kwiat, w którym się schowała, czyli lilia. To białe kwiecie uważane jest za symbol niewinności i braku złych zamiarów. Wydaje się więc, że w tym przypadku, podobnie jak w wyżej opisanej balladzie Kytice, dusza w postaci wiły pozwala na przetrwanie miłości poza ramami życia ziemskiego. Jednak w przeciwieństwie do wcześniej wspomnianego utworu, tym razem Erben potraktował temat bardziej ironicznie i stworzył tylko pozory dobrego wpływu świata dziwów na świat rze- 
czywisty. W balladzie młody mężczyzna, zakochany w wile, niespodziewanie zmuszony jest jechać na wojnę:

$$
\begin{aligned}
& \text { „Můj věrný milý!” tak mu píše král, } \\
& \text { „chci, abys zejtra ke službě mi stál; } \\
& \text { chci, aby přijel každý věrný lech, } \\
& \text { potřeba velká - všeho doma nech”. } \\
& \text { (Erben 2012, s. 138) }
\end{aligned}
$$

Podczas nieobecności syna, ukochaną opiekować się ma matka mężczyzny. Jednak jej działania doprowadzają do zwiędnięcia lilii i śmierci uwięzionej w niej duszy:

$$
\begin{aligned}
& \text { Špatně mu matka vůli plnila, } \\
& \text { špatně manželku jeho střežila; } \\
& \text { na nebi slunce - pobořena síň: } \\
& \text { „Zhyn, paní noční, zhyn, obludo, zhyn!” } \\
& \text { (Erben 2012, s. 138) }
\end{aligned}
$$

Wyjątkowo interesujący jest ostatni wers tego czterowierszu, w którym matka przeklina „panią nocy”. Czyżby znała ona podstępną nature wił i próbowała ochronić syna przed zgubnym związkiem? Choć syn przeklina matkę po powrocie z wojny, to może właśnie śmierć wiły wyrwała go z szaleńczej, toksycznej relacji - przecież szaleństwo to domena rodzienic. Erben wyraźnie pokazuje tutaj groźną relację pomiędzy kochankiem a wiłą, która doprowadziłaby najprawdopodobniej do całkowitego przejęcia kontroli nad mężczyzną przez demona ukrytego w niewinnie wyglądającej lilii.

Poetycki świat tomiku Kytice oferuje wiele oblicz „magicznego kwiecia", od gwarantujacej kontakt ze zmarłymi macierzanki, po ukrytą w białym kwieciu niebezpiecznej wiły. Erben z mistrzostwem wykorzystuje swoją wiedzę mitologiczną i folklorystyczną, by ukazać emocjonalne i społeczne rozterki mieszkańców dziewiętnastowiecznej czeskiej wsi.

\section{Literatura}

B r ü c k n e r A., 1985, Mitologia słowiańska i polska, wstęp i opracowanie S. Urbańczyk, Warszawa: PWN

Enge 1 king A., 2010, Klatwa. Rzecz o ludowej magii stowa, Warszawa: Oficyna Naukowa.

Erben K. J., 2012, Kytice, Praha: Československý spisovatel.

G i e y s zt or A., 1982, Mitologia Stowian, Warszawa: Wydawnictwo Artystyczne i Filmowe.

J a n i o n M., 2001, Natura, [w:] eadem, Prace wybrane, tom 4 Romantyzm i jego media, Kraków: Universitas.

Mac i oti M. I., 1998, Mity i magie ziót, przeł. I. Kania, Kraków: TAiWPN UNIVERSITAS

M a c u r a V., 1995, Znamení zrodu. České národní obrození jako kulturní typ. Praha: Melantrich.

N i e d z i e ls k i G., 2016, Dziewanna-pani lasów i gajów,

S t r z e l c z y k J., 1998, Mity, podania i wierzenia dawnych Stowian, Poznań: Rebis. 